\title{
PHARMACOGNOSTIC, PHYSICOCHEMICAL, AND PHYTOCHEMICAL STUDIES ON STEM BARK OF ZANTHOXYLUM ARMATUM DC.
}

\author{
JOTHI G*, KEERTHANA K, SRIDHARAN G \\ Department of Biochemistry, Srimad Andavan Arts and Science College (Autonomous), Tiruchirappalli, Tamil Nadu, India. \\ Email: jothi173@yahoo.com
}

Received: 16 October 2018, Revised and Accepted: 03 December 2018

\begin{abstract}
Objectives: To analyze the microscopic, macroscopic, physicochemical, and phytochemical standards of the Zanthoxylum armatum DC. (stem bark).

Methods: Pharamacognostic studies, namely macroscopic, microscopic, and powder microscopic analysis of stem bark were carried out. Physicochemical standards - ash content including total ash content, water soluble, and acid insoluble ash values, moisture content by loss on drying, solubility and extractive values of $Z$. armatum DC. were determined. Preliminary phytochemical screening, fluorescence analysis and quantification of alkaloids, flavonoids, phenol, tannins, saponins, and terpenoids were also studied.

Results: The macroscopic studies of stem bark showed the stem and its branches, armed with long, sharp prickles with variable size. The transverse section of bark showed the phellogen, phelloderm, cortex, phloem, and medullary rays that are characteristics to Z. armatum DC. The results of physicochemical standards give the identity and purity of the selected sample. Phytochemical studies revealed the presence of alkaloids, flavonoids, phenols, tannins, saponins, and terpenoids.
\end{abstract}

Conclusion: The present findings provide the pharmacognostic, physicochemical, and phytochemical information about the stem bark of $Z$. armatum and this might be useful by providing additional support with regard to its identification and standardization parameters.

Keywords: Zanthoxylum armatum DC., Pharmacognostic, Physicochemical, Phytochemical, Stem bark.

(C) 2019 The Authors. Published by Innovare Academic Sciences Pvt Ltd. This is an open access article under the CC BY license (http://creativecommons. org/licenses/by/4. 0/) DOI: http://dx.doi.org/10.22159/ajpcr.2019.v12i2.30292

\section{INTRODUCTION}

Plants are used as medicine from the time immemorial. About 2000 drugs of natural origin listed in Indian Materia Medica and most of them are derived from different traditional system and folklore practices [1]. The major sources of raw drugs are wild plants from local communities and herbal industries. The raw materials that are available in the markets are adulterated [2]. For safety and efficacy of the herbal product, accurate knowledge of crude drugs and its standardization studies becomes indispensable [3]. The importance of pharmacognosy has been widely felt in recent times. Standardization parameters, namely organoleptic, macroscopic, microscopic, physicochemical, phytochemical, and fluorescence studies helps to provide a unique identification of the plant even if the plant is in dry powder form and also helps to detect adulterations. Once the plant drug converted into dry powder, it loses its morphological identity and easily prone to adulteration. These kinds of studies will help in authentication of the plants and ensures reproducible quality of herbal products which will lead to safety and efficacy of plant drugs [4].

Zanthoxylum armatum (DC.) syn. Z. alatum a very important medicinal plant of Southeast Asia, belongs to the family Rutaceae commonly known as Timur (Nepal), Tejovathi (Sanskrit and Tamil), Indian prickly ash, Nepal pepper, or Tooth ache tree. It is an evergreen or sub deciduous shrub or occasionally very small tree with stem and branches, armed with long, sharp prickles found in Kashmir to Bhutan and also occurs throughout Northeast India. It is also found throughout China, Japan, Pakistan, Nepal, and Malaysia [5]. The Z. armatum (DC.) bark and fruit powder are used for the treatment of toothache [6]; its seeds and bark are used for the treatment of various diseases such as fever, cholera, heartburn, or indigestion [7]. It is reported for its antifertility [8], antiseptic, disinfectant, deodorant [9], antipyretic, and anti-diarrheal activities. It improves speech in children and increases saliva secretion [10]. Fruits and seeds of this plant are used in fever, dyspepsia, and skin diseases [11]. Leaves and bark were reported for hepatoprotective activity $[12,13]$, anticancer $[14,15]$, and antidiabetic activity $[16,17]$. However, no much scientific validation has been made for this plant; hence, the present study was aimed in the determination of pharmacognostic, physicochemical and phytochemical standards for the stem bark of Z. armatum DC.

\section{MATERIALS AND METHODS}

Collection of plant material

Plant source selected for the present study Z. armatum DC. (stem bark) and the authenticated bark material was bought from the Institute of Himalayan Bioresource Technology (Council of Scientific and Industrial Research), Himachal Pradesh, India. The bark was cleaned, shade dried and used for the present study.

Chemicals, reagents, and solvents

All chemicals, reagents, and solvents used for the study were analytical grade.

\section{Pharmacognostic study}

The stem bark of $Z$. armatum DC. was taken for macroscopic and microscopic analysis. The coarse powder was used for the physicochemical, fluorescence and phytochemical studies. The pharmacognostic studies such as macroscopic, microscopic, and powder microscopy were done by the procedure mentioned in standard literature [18-20].

\section{Florescence analysis}

Stem bark material was treated with various chemical reagents and exposed to visible, ultraviolet light to study their fluorescence behavior [21]. 
Physicochemical and phytochemical analysis

Physicochemical values such as the percentage of ash values and extractive values were determined according to the well-established procedure given in Indian Ayurvedic Pharmacopoeia [22]. Preliminary phytochemical screening was carried out to identify the presence of various secondary metabolites in stem bark of Z. armatum DC. [23] based on the change of color and/or precipitate formation after addition of specific reagents was observed. The quantitative analysis of major secondary metabolites such as alkaloids [24], flavonoids [25], phenols [26], terpenoids [27], tannins [28], and saponins [29] was determined according to the given standard procedures.

\section{RESULTS}

\section{Macroscopic studies}

Z. armatum DC. is an evergreen shrub or small tree (Fig. 1) The stem bark (Fig. 2) was taken for the macroscopic analysis. The color, appearance, taste, and odor of bark and powder were noted and given in Table 1. The macroscopic study of stem bark showed the stem and its branches, armed with long, and sharp prickles with variable size. The cork has large marks of tubercular prickles with 0.1-0.2 cm thickness. The external surface of stem bark looks pale brown in color and rough with numerous scattered patches of lenticels, slightly deeply furrowed. The internal surface was smooth, light yellow to pale brown with short fracture. The stem bark has aromatic odor with an aromatic pungent taste.

\section{Microscopical studies of bark}

The transverse section of stem bark was shown in Fig. 3a-c - The bark showed the presence of phellogen, phelloderm, cortex, phloem, and

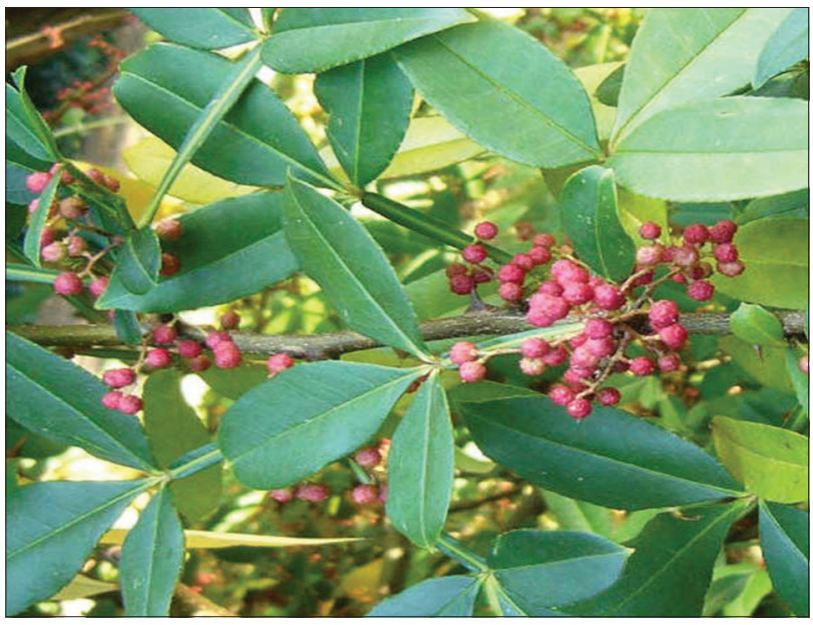

Fig. 1: Zanthoxylum armatum DC.

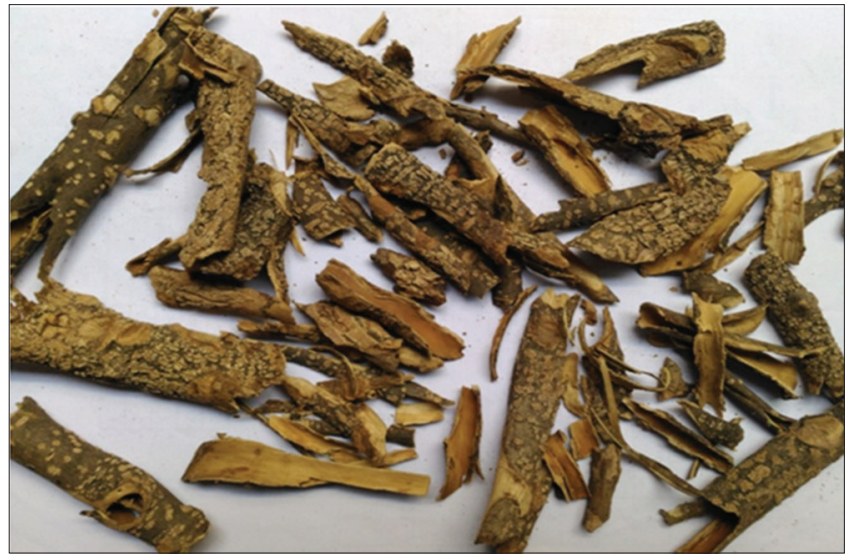

Fig. 2: Zanthoxylum armatum DC. Stem Bark medullary rays. The phellogen was made up of 5-6 layered collapsed rectangular and thick walled dead cells and some of these cells contain yellow/golden yellow colored cell content. Phellogen was followed by phelloderm which was contains 2-3 cell layered rectangular cells; some of this phelloderm cells contain compound and simple globular and ovoid starch grains and prismatic calcium oxalate crystals. Cortexes are several cells layered which was made up of ovoid/globular/ polygonal shaped parenchyma cells.

\section{Powder microscopy}

Powder microscopy studies of Z. armatum DC. (stem bark) indicated the presence of parenchymal cells containing yellowish brown content, prismatic calcium oxalate crystals, thick-walled fibers with narrow lumen and tapering ends, lignified parenchyma cells with thick lignified walls, macrosclereids with thick walls and pits, wide and branched central cavity, simple and compound, round, ovoid, polygonal, and irregular-shaped starch grains with centrally located hilum and the margins are striated, elongated sclereids, xylem vessels with spiral and pitted thickening and volatile oils are also seen in the study all these were shown in Fig. 4a-i.

\section{Fluorescence analysis}

The fluorescent analysis of stem bark of Z. armatum DC. on treatment with various chemical reagents showed different colors under day light and UV light. The results of fluorescent studies were given in Table 2. The green fluorescence indicates the presence of sterol, yellow fluorescence indicates the presence of flavonoids, and brown fluorescence indicates the presence of alkaloids.

\section{Physicochemical standards}

The physicochemical characteristics of stem bark powder, namely foreign matter, loss on drying, and ash values were given in Table 3. The result showed that the selected plant sample contained minimum amount of foreign matter $(0.82 \%)$ and moderate amount of moisture content $(6.134 \%)$. The total ash value was found to be $9.60 \%$ and water soluble ash content $3.12 \%$ was more than the acid insoluble ash $2.58 \%$. The chloroform $(9.67 \pm 0.58)$ and ethyl acetate $(8.63 \pm 0.76)$

Table 1: Morphological observation of Zanthoxylum armatum DC. (Stem bark)

\begin{tabular}{ll}
\hline Parameters & Observation \\
\hline Stem bark & \\
Color & Brown \\
Shape & Presence of spines and its mark on the rough surface \\
Taste & Bitter and astringent \\
Odor & Bitter and aromatic odor \\
Stem bark powder \\
Color & Yellow to brown \\
Taste & Bitter and astringent \\
Odor & Bitter and aromatic odor \\
\hline
\end{tabular}

Table 2: Fluorescence Analysis of powdered drug of Zanthoxylum armatum DC. (Bark)

\begin{tabular}{llll}
\hline S. No. & Treatment & Day light & UV light \\
\hline 1 & Drug Powder & Green & Green \\
2 & Drug powder+aq. 1N NaOH & Orange & Green \\
3 & Drug powder+alc. 1N NaOH & Yellow & Light green \\
4 & Drug powder+1N HCl & Light yellow & Light green \\
5 & Drug powder+50\% H2SO4 & Dark brown & Dark green \\
6 & Drug powder+Hexane & Colorless & Colorless \\
7 & Drug powder+Benzene & Light yellow & Light yellow \\
8 & Drug powder+Chloroform & Light yellow & Light yellow \\
9 & Drug powder+Ethyl acetate & Light yellow & Light yellow \\
10 & Drug powder+Alcohol & Light yellow & Light yellow \\
11 & Drug powder+Acetone & Light yellow & Pink \\
12 & Drug powder+Water & Yellow & Green \\
\hline
\end{tabular}


extractive values were higher when compared to hexane extractive value $4.2 \pm 0.26$. This indicates the presence of high polar compounds. The water solubility was found to be higher when compared to alcohol solubility.

\section{Qualitative and quantitative analysis of secondary metabolites}

The preliminary phytochemical screening of dry powder and its various extracts of stem bark of $Z$. armatum DC. given in Table 4 and the results revealed the presence of variety of the phytochemicals in different extracts. Aqueous extracts revealed the presence of alkaloid, flavonoid, phenol, glycoside, lignin, coumarin, and tannin. Saponin, sterol, and terpenes were absent in aqueous extract. Ethanolic extract showed the presence of saponin, tannin, terpenes, flavonoid, alkaloid, coumarin, lignin, glycoside sterol, and phenol. Saponin, flavonoid, lignin, alkaloid, sugar, and phenol were present in chloroform extracts. Sterol, terpenes, flavonoid, coumarin, lignin, alkaloid, and phenol were present in ethyl acetate extract. In hexane extract, saponin, terpene, coumarin, and alkaloids were present. The drug powder showed the presence of alkaloid tannin, coumarin, glycoside, sugar, and phenol.

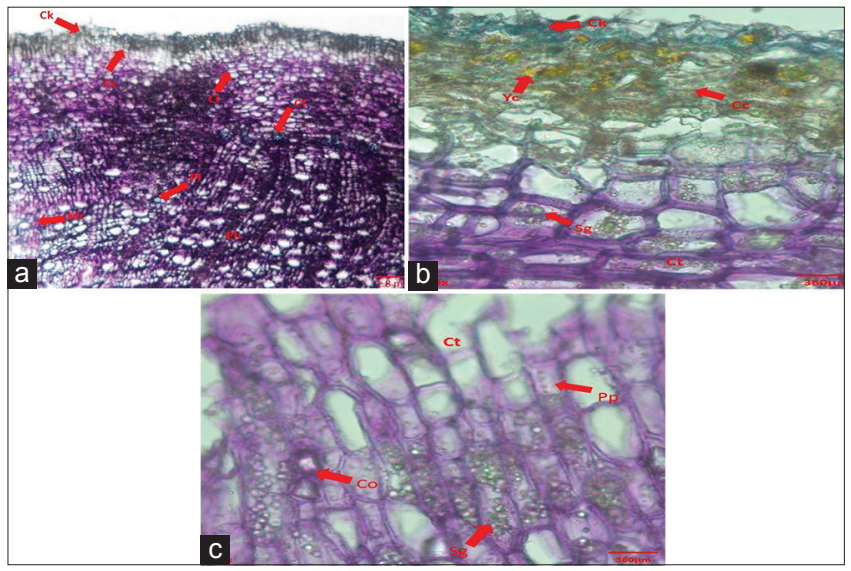

Fig. 3: (a) TS of Zanthoxylum armatum DC. (Bark). (b) TS of Z. armatum DC. (Bark). (c) TS of Z. armatum DC. (bark) Enlarged view. Cc - Cork cambium, Cf - Cortical fiber, Ck - Cork, Co - Calcium oxalate crystals (prismatic), $\mathrm{Ct}$ - cortex, Sc - Sclereids, Mr medullary ray, Pf - Phloem fiber, Pp - Parenchyma with pits, Sg Starch grains, Yc - Yellow cell content

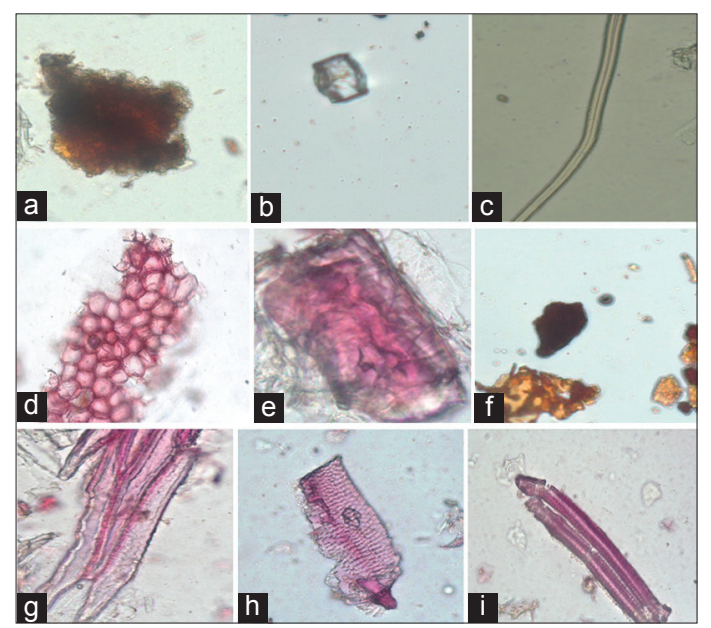

Fig. 4: Powder microscopy of Zanthoxylum armatum DC. Bark.

(a) Brown content $(\times 400)$. (b) Prismatic calcium oxalate crystal

$(\times 400)$. (c) Fiber $(\times 400)$. (d) Lignified parenchyma $(\times 400)$.

(e) Sclereids $(\times 400)$. (f) Starch grain $(\times 400)$. (g) Elongated sclereids $(\times 400)$. $(h)$ Xylem vessels with pitted thickening $(\times 400)$. (i) Xylem vessels with spiral thickening $(\times 400)$
The quantitative analysis of major secondary metabolites in the Z. armatum DC. shows in Table 5. Alkaloid content was found to be higher, followed by saponin, terpenoid, and flavonoid.

\section{DISCUSSION}

The standardization studies of a crude drug are an integral part for establishing its correct identity, purity, and quality of the raw drug material. Before including any crude drug an herbal pharmacopeia, pharmacognostic parameters such as anatomy, macroscopy, and microscopy including powder microscopic standards must be established. The microscopic method is one of the simplest and cheapest methods to start with for establishing the correct identity of the source materials [30-34]. In the present study, from the results obtained, the macroscopic and microscopic features of stem bark of Z.armatum DC. were identified and depicted (Fig. 3a-c).

The crude drugs from plant origin were the major source of drug used in the Indian medicinal system. To check the identity, purity and quality of the crude drug the pharmacognostic and physicochemical standards were followed before it comes to use or marketing. This will helps to assess the quality of the drugs. The presence of a decreased level of foreign matter indicates the purity of the collected plant materials of the selected plant [35]. According to the World Health Organization (WHO), the macroscopic and microscopic description of a medicinal plant is the first step toward establishing its identity and purity and should be carried out before any tests are undertaken [36]. In the present study, the macroscopic features of stem bark of Z armatum were studied and it serves as diagnostic parameter. Microscopic study of stem bark including powder microscopy resulting the presence of cork interrupted by lenticels, stone cells, phloem arrangements, calcium oxalate crystals, oil globules, and starch grains indicates the characteristics of stem bark.

Physicochemical standards such as ash content, moisture content using the loss on drying, extractive values give the identity, purity, and strength of the selected drug (Table 3). Ash values are used to determine the quality and purity of crude drug. It indicates the presence of various impurities such as carbonate, oxalate, and silicate in the drug source decrease the quality and efficiency of selected drug. The water-soluble ash is used to estimate the amount of inorganic compound and the acid insoluble ash consists mainly of silica and indicate contamination with earthy material. Moisture content of drugs could be at minimal level to discourage the growth of bacteria, yeast, or fungi during storage and it is mentioned in Ayurvedic Pharmacopoeia of India for number of medicinal plants. In the present study, the ash values including water soluble and acid insoluble ash of stem bark of $Z$. armatum DC. were determined and do not exceeding the prescribed values given in Ayurvedic Pharmacopoeia. The extractive values are useful to evaluate the chemical constituents present in the crude drug and also help in estimation of specific constituents soluble in a particular solvent [37].

Table 3: Physicochemical characteristics of Zanthoxylum armatum DC. (Bark)

\begin{tabular}{ll}
\hline Parameters & Value $\% \mathbf{~ W / W}$ \\
\hline Foreign matter & 0.82 \\
Loss on drying & $6.134 \pm 0.15$ \\
Total ash content & $9.60 \pm 0.35$ \\
Water soluble ash & $3.12 \pm 0.26$ \\
Acid-insoluble ash & $2.58 \pm 0.69$ \\
Extractive values (\%) & \\
Hexane & $4.2 \pm 0.26$ \\
Chloroform & $9.67 \pm 0.58$ \\
Ethyl acetate & $8.63 \pm 0.76$ \\
Solubility values & \\
Alcohol & $11.21 \pm 0.40$ \\
Water & $16.11 \pm 0.55$ \\
\hline Values are expressed &
\end{tabular}


Table 4: Preliminary phytochemical screening of Zanthoxylum armatum DC. (Bark)

\begin{tabular}{|c|c|c|c|c|c|c|c|}
\hline S. No & Test for & Drug powder & Hexane & Chloroform & Ethyl acetate & Ethanol & Water \\
\hline 1 & Saponin & - & + & + & - & + & + \\
\hline 2 & Tannin & + & - & - & - & + & + \\
\hline 3 & Sterol & - & - & - & + & + & - \\
\hline 4 & Terpene & - & + & - & + & + & - \\
\hline 5 & Flavonoid & - & - & + & + & + & + \\
\hline 6 & Coumarin & + & + & - & + & + & + \\
\hline 7 & Lignin & + & - & + & + & + & + \\
\hline 9 & Glycoside & + & - & - & - & + & + \\
\hline 10 & Sugar & + & - & + & - & - & + \\
\hline 11 & Phenol & + & - & + & + & + & + \\
\hline
\end{tabular}

+: Positive indicates presence, -: Negative indicates absence

Table 5: Quantitative analysis of secondary metabolites

\begin{tabular}{lll}
\hline S. No & Content & Value $(\mathbf{m g} / \mathbf{g})$ \\
\hline 1 & Total alkaloids & $2.73 \pm 0.23$ \\
2 & Total flavonoids & $0.05 \pm 0.02 \mathrm{QE}$ equivalent \\
3 & Trpenoids & $153 \pm 3.21$ \\
4 & Saponin & $0.13 \pm 0.01$ \\
5 & Tannin & $0.041 \pm 0.01$ \\
6 & Phenol & $25.92 \pm 1.36 \mathrm{GAE}$ equivalent \\
\hline
\end{tabular}

Values are expressed in mean \pm SD where $n=3$. QE: Quercetin equivalent, GAE: Gallic acid equivalent

The extractive values of the selected drug are useful to evaluate the chemical constituents present in crude drug and also help in estimation of specific constituents soluble in particular solvents. The water solubility was found to be higher followed by alcohol extractive in the stem bark chosen for the current study. The fluorescent analysis under day light and UV light by treatment with different chemical reagents showed different colors (Table 2). It indicates the presence of active ingredients, and it is the preliminary test for the presence of various secondary metabolites. The preliminary phytochemical screening and quantitative analysis of Z. armatum DC., stem bark showed the presence of various secondary metabolites such as alkaloids, flavonoids, phenol, tannin, saponin, terpenoids, glycosides, and coumarin and some of the major secondary metabolites quantity were also determined. The phytochemical compounds are known to exhibit bioactive properties. Different alkaloids have been isolated from several medicinal plants and investigated for their possible antidiabetic activity in different animal models. The preliminary phytochemical screening and its estimation (Tables 4 and 5) may be useful in the detection of the bioactive principles and subsequently may lead to the drug discovery and development.

Qualitative and quantitative analysis of secondary metabolites is very essential for identifying the presence of phytochemicals which is important for the contribution of medicinal as well as physiological properties to the plants. The curative properties of medicinal plants are perhaps due to the presence of various secondary metabolites such as alkaloids, flavonoids, glycosides, phenols, saponins, and steroids, etc. [38]. The present study revealed that the stem bark of Z. armatum DC. is a rich source for phytochemicals and can be used as the best source for the treatment of different ailments.

\section{CONCLUSION}

In the current study, the macroscopic, microscopic, physicochemical, and phytochemical studies of Z. armatum DC. (stem bark) were determined. The pharmacognostic and physicochemical and phytochemical parameters provide the authentication source, standardization and therapeutical information of the selected drug source. In conclusion, the above finding gives the pharmacopeial and pharmacological information for further studies.

\section{ACKNOWLEDGMENT}

The authors express sincere thanks to University Grant Commission for providing financial support to carry out the study under Major Research Project Scheme (F. No 43 - 40/2014 (SR) (05/08/2015)).

\section{AUTHORS' CONTRIBUTIONS}

Designed the experiments Jothi G. and Sridharan G, Performed and drafted by Keerthana K and Jothi G. All authors contributed for the final version.

\section{CONFLICTS OF INTEREST}

The authors declare that they have no conflicts of interest.

\section{REFERENCES}

1. Narayana DB, Katayar CK, Brindavanam NB. Original system: Search, research or research. IDMA Bull 1998;29:413-6.

2. Nivedithadevi D, Somasundaram R. Pharmacognostical and qualitative phytochemical studies on the aerial parts of Tephrosla purpurea (L). Int J Res Biol Sci 2012;2:48-53.

3. Chanda S. Importance of pharmacognostic study of medicinal plants: An overview. J Pharm Phytochem 2014;2:69-73.

4. Ministry of Health and Family Welfare, Department of Ayush. The Ayurvedic Pharmacopoeia of India. $1^{\text {st }}$ ed. New Delhi: Government of India, Ministry of Health and Family Welfare, Department of Ayush; 2007. p. 168

5. Dikshit A, Hussain A. Antifungal activities of some essential oils against animal pathogens. Fitoterapia 1984;55:171-6.

6. Jain SR, Jain MR. Antifungal studies on some indigenous volatile oils and their combinations. Planta Med 1972;22:136-9.

7. Shah GM, Khan MA. Checklist of Medicinal Plants of Siran Valley. Mansehra, Pakistan: Ethnobot Lealf; 2006. p. 63-71.

8. Shinwari ZK, Watanabe T, Rehman M, Yoshikawa T. A Pictorial Guide to Medicinal Plants of Pakistan. Kohat: Published by KUST; 2006.

9. Ahmad S, Ali A, Beg H, Dasti AA, Shinwari ZK. Ethnobotanical studies on some medicinal plants of Booni valley, District Chitral, Pakistan. Pak J Weed Sci Res 2006;12:183-90.

10. Khare CP. An Illustrated Dictionary. Berlin, Heidelberg: SpringerVerlag; 2007. p. 730.

11. Verma N, Khosa RL. Hepatoprotective activity of leaves of Zanthoxylum armatum DC in CCl4 induced hepatotoxicity in rats. Indian J Biochem Biophys 2010;47:124-7.

12. Ranawat L, Bhatt J, Patel J. Hepatoprotective activity of ethanolic extracts of bark of Zanthoxylum armatum $\mathrm{DC}$ in $\mathrm{CCl} 4$ induced hepatic damage in rats. J Ethnopharmacol 2010;127:777-80.

13. Singh TD, Meitei HT, Sharma AL, Robinson A, Singh LS, Singh TR. Anticancer properties and enhancement of therapeutic potential of cisplatin by leaf extract of Zanthoxylum armatum DC. Biol Res 2015;48:46.

14. Mukhija M, Singh MP, Dhar KL, Kalia AL. Cytotoxic and antioxidant activity of Zanthoxylum alatum stem bark and its flavonoid constituents. J Pharm Phytochem 2015;4:86-92.

15. Baral SR, Kurmi PP. A Compendium of Medicinal Plants in Nepal. Kathmandu: Mrs Rachana Sharma Publication; 2006.

16. Karki H, Upadhayay K, Pal H, Singh R. Antidiabetic potential of Zanthoxylum armatum bark extract on streptozotocin-induced diabetic rats. Int J Green Pharm 2014;45:77-83. 
17. Rynjah CV, Devi NN, Khongthaw N, Syiem D, Majaw S. Evaluation of the antidiabetic property of aqueous leaves extract of Zanthoxylum armatum DC. Using in vivo and in vitro approaches. J Trad Comp Med 2018;8:134-40.

18. Amponsah IS, Mensah AY, Otoo A, Mensah ML, Jonathan J. Pharmacognostic standardisation of Hilleria latifolia (Lam.) H. Walt. (Phytolaccaceae). Asian Pac J Trop Biomed 2014;4:941-6.

19. Khandelwal KR. Practical Pharmacognosy. $10^{\text {th }}$ ed. Pune: Nirali Publication; 2003

20. Thitikornpong W, Phadungcharoen T, Sukrong S. Pharmacognostic evaluations of Lagerstroemia speciosa leaves. J Med Plant Res 2011;5:1330-7.

21. Edwin S, Joshi SB, Jain DC. Comparative pharmacognostic studies on root powder of Plumbago zeylanica and Plumbago rosea. Indian J Nat Prod 2008:2:27-9.

22. Controller of Publications. Indian Ayurvedic Pharmacopoeia. Vol. 2. New Delhi: Controller of Publications.

23. Brindha P, Bhimarao S. Pharmacognostic Studies on Coleus Aromatic Benth. Indian Berage, B.M.E.B.R; 1981. p. 17-31

24. Harborne JB. Phytochemical Methods: A Guide to Modern Techniques of Plant Analysis. New York: Chapman and Hall; 1984. p. 1-89.

25. Swain T, Hillis E. The phenolic constituents of Prunus domestica I. The quantitative analysis of phenolic constituents. J Sci Food Agric 1959;10:63-8

26. Ferguson NM. A Text Book of Pharmacognosy. New Delhi: Mac Milan Company; 1956. p. 191

27. Malik EP, Singh MB. Plant Enzymology and Hittoenzymology. 1st edn. New Delhi: Kalyani Publishers; 1980. p. 286.

28. Krishnaiah D, Devi T, Bono A, Sarbatly R. Studies on phytochemical constituents of six Malaysian medicinal plants. J Med Plants Res 2009;3:67-72
29. Hiai S, Oura H, Nakajima T. Color reaction of some sapogenins and saponins with vanillin and sulfuric acid. Plant Med 1976;29:116-22.

30. Singh S, Machawal L, Chauhan MG. Pharmacognostic study of male leaves of Trichosanthes dioica Roxb. With special emphasis on microscopic technique. J Pharm Phytother 2010;2:71-5.

31. Kapoor M, Jasani N, Acharya N, Acharya S, Kumar V. Phytopharmacological evaluation and anti-asthmatic activity of Ficus religiosa leaves. Asian Pac J Trop Med 2011;4:642-4.

32. Jothimani R, Karthikeyan K, Balasundaram J. Phytochemical and pharmacological evaluation of prop roots of Pandanus fascicularis Lam. Asian Pac J Trop Med 2011;4:649-53.

33. Lachumy SJ, Sasidharan S, Sumathy V, Zuraini Z. Pharmacological activity, phytochemical analysis and toxicity of methanol extract of Etlingera elatior (torch ginger) flowers. Asian Pac J Trop Med 2010;3:769-74.

34. Bragadeeswaran S, Thangaraj S, Rajiv CR, Balaji D. Pharmacological and biomedical properties of sea anemones Paracondactylis indicus, Paracondactylis sinensis, Heteractis magnifica and Stichodactyla haddoni from East coast of India. Asian Pac J Trop Med 2011;4:722-6.

35. Keerthana K, Jothi G, Gurunagarajan S, Nayagam AA. Microscopic, physicochemical and phytochemical studies of Gardenia jasminoides. [Ellis]. Int J Pharm Pharm Sci 2018;10:97-102.

36. WHO. Quality Control Methods for Medicinal Plants. Geneva: WHO; 2002. p. 28-31.

37. Thomas S, Patil DA, Patil AG, Chandra N. Pharmacognostic evaluation and physicochemical analysis of Averrhoa carambola L. Fruit. J Herb Med Toxicol 2008;2:51-4

38. Britto JD, Sebastian SR. Biosynthesis of silver nano particles and its antibacterial activity against human pathogens. Int J Pharm Pharm Sci 2011;5:257-9. 